\title{
Bacterial Leaf Spot of Amaranthus cruentus L. Caused by Burkholderia andropogonis (Stapp) Gills et al.
}

\author{
Yuichiro MURA＊ and Masao Goto**
}

Key words : new bacterial disease, Amaranthus cruentus, Burkholderia andropogonis.

This paper deals with a new bacterial disease of Amaranthus cruentus L. (Japanese common name: Amaransasu or Sen Nin Koku) that was introduced from South America and grown in Japan locally either as a grain crop for white seeds, a vegetable for green leaves or an ornamental for yellow to red, upright flowers. This is the first record of bacterial leaf spot caused by Burkholderia (Pseudomonas) andropogonis ${ }^{3)}$ on the plants of Amaranthaceae.

Although the disease occurred from June through October, the most severe incidence was observed in July and August. The earliest symptom was dark green, water-soaked dots on leaf blades. They gradually enlarged to form circular spots a few to several $\mathrm{mm}$ in diameter and light brown to reddish brown in color. The spots were invariably surrounded by distinct yellow haloes 1 to $2 \mathrm{~mm}$ in diameter. The undersurface of the lesions was often greasy in appearance. The spots were usually scattered over leaf blades, but sometimes formed along veins. The disease development usually began from lower leaves, gradually spreading to upper leaves (Fig. 1A).

From diseased leaves collected at different fields in Shizuoka Pref., 6 strains (Am1-Am6) were isolated on nutrient agar plates by conventional method. A strain of $B$. andropogonis (Pa1) was isolated from sorghum which was affected by bacterial stripe disease in the experimental farms of MOA Nature Farming School.

By spray and prick inoculation methods, strains Am1-Am6 and Pa1 produced light brown to brown spots with yellow haloes on leaves of $A$. cruentus, black spots on leaves of white clover and alfalfa (cv. Natsuwakaba) and red stripes on sorghum (Fig. 1B), respectively. The symptoms on these plants except for alfalfa were identical with those produced by the infection under natural conditions. No difference was observed between strains Am1-Am6 and strain Pa1 in the symptoms and the disease severity produced on these plants. Both bacteria did not produce any symptoms on the following plants: Italian millet (cv. unknown), proso millet (cv. unknown), rice (cv. Koshihikari), oat (cv. unknown), radish (cv. Hatsukadaikon), Brassica campestris (cv. Jikyona), Amaranthus tricolor L. (cv. Morten- fire), A. mangostanus L., Celosia cristata var. childsii Hort (cv. Yachiyo keito), kidney bean (cv. Eburon), carrot (cv. Kuroda-gosun-ninjin), tobacco (cv. Bright yellow 4), tomato (cv. Momotaro), spinach (cv. Sanraito), welsh onion (cv. Akihiko), Chrysanthemum coronarium (cv. Satoyutaka), lettuce (cv. Shisuko), Calendula and Corchorus olitorius. All strains were negative in potato tuber rot and tobacco hypersensitive reaction.

Unless otherwise mentioned, the methods described by Cowan $^{2)}$ were applied for the tests of physiological and biochemical properties. Strains Am1-Am6 and Pa1 were identical in the bacteriological properties with an exception of sorbitol utilization. Growth was relatively slow on nutrient agar plates, reaching to about $1 \mathrm{~mm}$ in diameter in 3 to 4 days at $28^{\circ} \mathrm{C}$. Colonies were white, smooth, circular, convex, translucent with entire margins, and became very sticky when aged. Cells were Gram-negative, nonsporing, straight rods with round ends and motile with one to rarely two polar flagella. Poly- $\beta$-hydroxybutyrate granules were readily detected when grown on a synthetic basal medium of Ayers et al. with glucose as a sole source of carbon. All strains metabolized glucose oxidatively, turned litmus milk blue without coagulation and digestion, and grew in nutrient broth containing $3 \% \mathrm{NaCl}$ but not $4 \%$. Catalase reaction was positive. All strains were negative in the following tests: hydrolysis of casein, esculin, gelatin, pectin, starch and Tween 80, activities of arginine dihydrolase, lecithinase, urease and oxidase, production of pyoverdin on King's B medium, levan, acetoin, hydrogen sulfide, indole, and reducing substances from sucrose. All strains either produced acid from the following substances or used as a sole source of carbon: arabinose, ribose, fructose, galactose, glucose, mannose, rhamnose, adonitol, glycerol, inositol, mannitol, acetic acid, citric acid, folic acid, fumaric acid, galacturonic acid, gluconic acid, lactic acid, malic acid, malonic acid, succinic acid, alanine, tryptophan and tyrosine. Strains Am1, Am4, Am6 and $\mathrm{Pa} 1$ were positive in utilization of sorbitol, but Am2, Am3 and Am5 were negative. The following substances were not utilized as a sole source of carbon: xylose, cellobiose, melibiose, maltose, trehalose, sucrose, melezitose, raffinose, dextrin, inulin, starch, $\alpha$ -

\footnotetext{
* MOA Nature Farming School, Ukihasi 1606, Ohito-cho, Takata-gun, Shizuoka 410-23, Japan

** Faculty of Agriculture, Shizuoka University, Ohya 836, Shizuoka 422, Japan 静岡大学農学部 


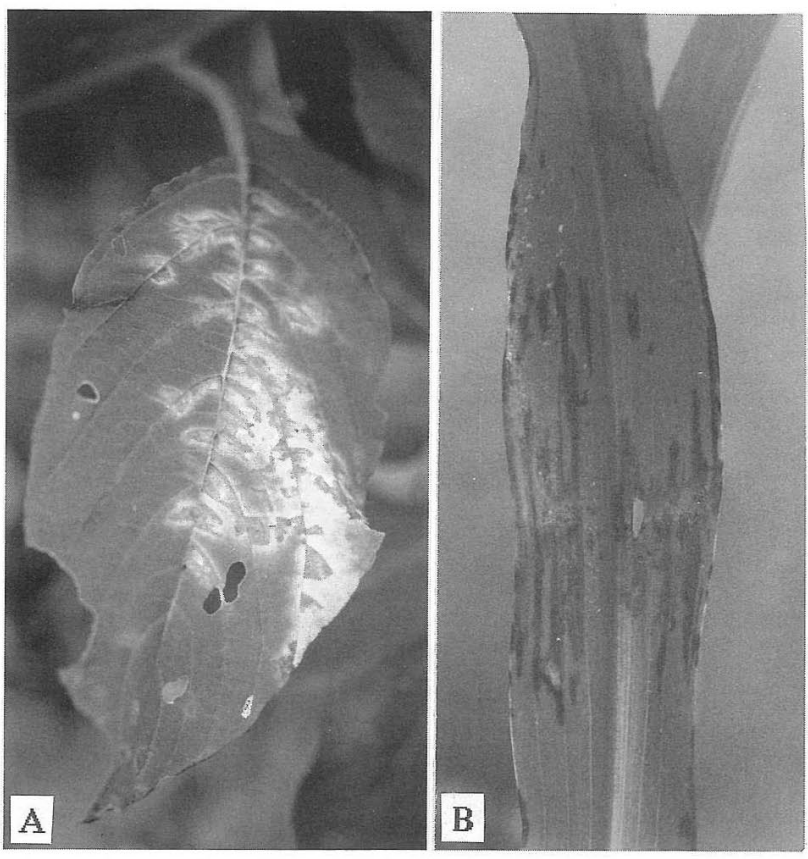

Fig. 1. A. Symptoms of bacterial leaf spot of Amaranthus cruentus in nature. B. Symptoms produced on sorghum by artificial inoculation of strain Am2.

methyl-D-glucoside, arbutin, esculin, salicin, dulcitol, erythritol, ethanol, geraniol, propanol, benzoic acid, glycolic acid, maleic acid, oxalic acid, propionic acid, tartaric acid, histidine and leucine.

In literature, four pathogenic bacteria have been listed on Amaranthus spp.: Agrobacterium tumefaciens, Pseudomonas syringae pv. tabaci, Burkholderia solanacearum and Xanthomonas campestris pv. amaranthicola ${ }^{1)}$. Among them, $P$. s. pv. tabaci and $X$. c. pv. amaranthicola are discernible as the leaf spot pathogens. However, the present bacterium was clearly differentiated from these bacteria in many phenotypic properties including production of pigments, capacity to hydrolyse high molecular substances, and ability to use carbohydrates as a sole source of carbon. Thus, the bacterium under consideration was determined to be a new pathogen that have never been reported on Amaranthus spp.

From the bacteriological characteristics and host ranges, strains Am1-Am6 isolated from Amaranthus cruentus were identical with strain $\mathrm{Pa}$ isolated from bacterial stripe disease of sorghum. Therefore, we identified the amaranthus strains as Burkholderia andropogonis, and propose bacterial leaf spot (Japanese common name: Hanten-saikin Byō) as the common name of the disease.

This bacterium has been known by wide natural hosts including 33 species of 21 genera belonging to 12 families of Caryophyllaceae, Commelinaceae, Ericaceae, Graminiae, Leguminosae, Liliaceae, Musaceae, Nyctaginaceae, Orchidaceae, Plumbaginaceae, Polygonaceae and Rubinaceae ${ }^{1,7)}$. In addition, other 14 species of 13 genera have been reported to be susceptible by inocula- tion tests ${ }^{1)}$. In this paper, Amaranthus cruentus of the family Amaranthaceae was added to the list of natural hosts, suggesting that the host range of this bacterium may be further expanded in future. Some strains of $B$. andropogonis have been reported to be nonpathogenic to white clover ${ }^{5,7)}$, implying the possible existence of the host specialization in this bacterium. In Amaranthus spp., the disease susceptibility greatly varied among species. Similar phenomenon has already been observed in Sorghum $\mathrm{spp}^{6)}$. B. andropogonis produces rhizobitoxine ${ }^{4)}$ and another toxin that is similar to tabtoxin in respect to the bioassay with $E$. coli ${ }^{5}$. It is an open question which toxin could be involved in the development of yellow haloes on the leaves of $A$. cruentus.

We thank Dr. M. Hirano of Iwate University for identification of Amaranthus cruentus and Dr. Y. Takikawa of Shizuoka University for his advice and assistance.

\section{Literature cited}

1. Bradbury, J.F. (1986). Guide to Plant Pathogenic Bacteria, CAB International Mycological Institute, Kew, England.

2. Cowan, S.T. (1974). Manual for the Identification of Medical Bacteria, 2nd ed., Cambridge University Press, Cambridge.

3. Gills, M., Van, T.V., Bardin, R., Goor, M., Hebbar, P., Willems, A., Segers, P., Kersters, K., Heulin, T. and Fernandez, M.P. (1995). Polyphasic taxonomy in the genus Burkholderia leading to an emended description of the genus and proposition of Burkholderia vietnamiensis sp. nov. for $\mathrm{N}_{2}$-fixing isolates from rice in Vietnam. IJSB 45 : 274-289.

4. Mitchell, R.E. and Coddington, J.M. (1991). Biosynthetic pathway to rhizobitoxine in Pseudomonas andropogonis. Phytochemistry $30: 1809-1814$.

5. Moffett, M.L., Hayward, A.C. and Fahy, P.C. (1986). Five new hosts of Pseudomonas andropogonis occurring in eastern Australia : host range and characterization of isolates. Plant Pathol. 35 : 34-43.

6. Muntanola, M. (1950). Bacteriosis of sorghum due to Pseudomonas andropogonis (E.F. Smith) Stapp in the Argentine Republic. Lilloa 23: 307-317 (Rev. Plant Pathol. 31: 487, 1952).

7. Togawa, M. and Takikawa, Y. (1991). Bacterial brown spot of Ruscus sp. caused by Pseudomonas andropogonis. Ann. Phytopathol. Soc. Jpn. 57 : 729-731.

\section{和 文 摘 要}

村井雄一朗・後藤正夫：Burkholderia andropogonis による Amaranthus cruentus の斑点細菌病（新称）

Amaranthus cruentus（和名：アマランサス；仙人穀）の葉 に黄色の軍を伴う褐色ないし赤褐色，直径数 $\mathrm{mm}$ の円形斑点を つくる細菌病が発生した。病原細菌は普通寒天平板上で比較的 生育の遅い, 粘性の白色集落を形成した。この細菌は $A$. cruentus の葉に自然発病と同じ病斑を形成してコッホの原則を 満たしたほか, モロコシに赤色条斑をまたシロクローバおよび 
アルファルファ上に黒色病斑を生じた。一方, アマランサス科の ハゲイトウ，ヒユナ，ケイトウをはじめ 17 種の植物には病原性 を示さなかった。本細菌の細菌学的性状は,ソルビトール分解能 で陽性と陰性を示す菌株が存在したほかは，モロコシ条斑細菌 病菌 (Burkholderia (Pseudomonas) andropogonis) のそれと完
全に一致した。これらの性状から本細菌をB. andropogonis と 同定し, 病名をアマランサス斑点細菌病と呼称することを提案 する。

(Received December 4, 1995 ; Accepted January 18, 1996) 